\title{
Learning Design of Indonesian Phonology Based on Digital Learning Management System
}

\author{
M. Oky F. Gafari ${ }^{1}$, Achmad Yuhdi ${ }^{2}$ \\ \{oky@unimed.ac.id\} \\ Indonesian Literature Program State University of Medan, Indonesia ${ }^{1,2}$
}

\begin{abstract}
The 4.0 industrial revolution that occurs today, demands the changes of learning process in universities towards learning based on digital. The form of digitalization of the learning process will later penetrate the boundaries of space and time that have been blocking the interaction between the lecturers and the students. This simple writing, then will describe the design of the digital learning process in colleges. The digitalization in this paper means an android-based learning design utilizing software/learning management system (LMS) for activities in the network (online) in Indonesian phonology courses. Some features that can be utilized in managing LMS based learning are: a) Courses, with courses menu, the users can create new classes, join classes that have already existed or browse through the predefined class list. b) Groups which functions like the wall messages of the group members and can also post on the wall messages. When joining a group, the users can search for parts of the group that the users want. c) Resources are to maintain, to track the documents, files and images that users upload in the class. d) Recent Activity is to display the latest news contained in the account. e) Calendar, to display the calendar page that was posted earlier in the Recent Activity. f) Messages are to send messages or view the messages among the fellow users, and g) People is to be able to see a list of the users in a class.
\end{abstract}

Keywords: learning management system, college.

\section{Introduction}

There are five components that are very important in learning activities. They are goals, materials, methods, media, and learning evaluation. These five aspects influence among and other. The choice on one certain teaching method will have an impact on the appropriate type of learning media, without forgetting three other important aspects, they are goals, material, and evaluation of learning. In this case, it can be said that one of the main functions of learning media is as a teaching aid that also influences the motivations, conditions, and the learning environment (Hamalik, Oemar. 1990).

Furthermore, Kemp and Dayton (in Yamin and Martinis: 2006) explain in detail the benefits of learning media as: 1) instrument for delivering the learning material, 2) the learning process becomes more interesting, 3) the learning process becomes interactive, 4) efficiency in time and energy, 5) improving the quality of student learning outcomes, 6) allowing the learning process to be carried out anywhere and anytime, 7) improving the students' positive attitudes towards the material and learning process, 8) changing the students' role to be more positive and productive, and 9) making the abstract learning material becomes concrete. 
Along the time, learning media continues to grow following the rapid wave of information technology change. At first the media was only considered as teaching aids. The instruments used are visual aids, such as models, objects and other tools that can provide concrete experiences, learning motivation and enhance absorption or learning retention. However, at present the learning media are required to be able to penetrate the boundaries of space and time which have been a barrier in learning activities. For that reason, the educators are required to be able to design internet-based learning media that can be used as a means of blended learning.

One the information $t$ echnology development products today is a Linux-based operating system which was designed for touch screen hand phone devices and tablet computers which is called android. As quoted from Tribun on February 26, 2017, the average Indonesian people spend 5.5 hours playing an Android-based cell phone from waking up to go back to sleep. The time tendency of the students spend with their smart phones can be used as opportunities and threats to the success of the learning process. The lecturers' role as educators in developing android-based learning media with the LMS (learning management system) system needs to be improved.

The Android-based learning is one activity that offers mixed learning/blended learning face-to-face learning in class and in cyberspace/ in the network. The learning process is easy to use such as using Facebook. The Android-based learning will help the lecturers in opening wide communication opportunities for students so that they are easier to take part in discussions and be cooperative in learning activities. In addition, the Android-based learning also has many interesting features and functions to be used by students. The Applications that can be used in the Android-based learning include Edmodo and Schoology. The LMS design in this paper is an LMS-based android learning using Schoology application.

The activity and the research related to Schoology media have been conducted by the teachers and the researchers. Putri Sugiyarto (2017) in her study at SMKN VII Surabaya states that the learning outcomes of the students who used learning media of e-learning Schoology were better than the students who did not use learning media of e-learning Schoology. In addition, the results of the study showed that the learning media of e-learning Schoology received a percentage of responses categorized as very feasible from experimental class students.

Labo (2016) in his research related to the use of Schoology to increase the student learning activities in the Citizenship Education course at SMA Negeri 1 Tengaran presented the results that there was an increase in percentage. With an explanation of $42.08 \%$ at the first meeting, then at the second meeting it was $67.08 \%$, while at the last meeting it was $88.52 \%$. From this percentage increase, it can be concluded that Schoology media has a good impact on increasing student activity in learning.

The advantages of Schoology were also examined by Ansor (2015). His research related to the difference in the effect of using E-Learning based on Schoology and Edmodo on the independence and learning achievement ofmathematics resulted in the conclusion that the Schoology media is more effective in increasing the students' independence in learning mathematics. Of the three researches raised by the authors it can be seen that Schoology media has a number of advantages, they are: it can improve the learning achievement, get a positive response, increase learning activities, and can improve learning independence.

Based on the research results, it showed positive values on the results of learning using e learning media of Schoology, the activities of this study will develop Android-based learning media using Schoology in the Indonesian Phonology course at Indonesian Literature Study 
Program of FBS Unimed. However, the discussion in this article is still in the design stage of Android-based learning media products for the Indonesian Phonology course.

\section{Research methods}

This research approach uses research and development (R\&D). This development design is Research and Development or Research Development. The development is in the form of the development of Android-based e-learning media by using the Schoology application as a learning supplement for the Indonesian Language Phonology course at the Indonesian Literature Study Program of FBS Unimed. This article is a Second phase as part of the research and development activities carried out which is the design phase of the program. In this phase, it transfers the obtained information from the analysis phase into the form of documents that will be the purpose of the developed media, one of the documents produced is a storyboard document. So, the research method used in writing this article is a descriptive research method. Some of the things described in this article are the integration of Indonesian Phonology learning materials into the Schoology learning media.

\section{Research resulth and discussion}

The meaning of Schoology according to Aminoto, T and Pathoni (2014: 21) is a website that combines e-learning and social networking. The concept is the same as Edmodo, but Schoology has many advantages. Building elearning with Schoology is also more profitable than using moodle, because it does not require hosting and managing Schoology (more friendly users). Certainly, the features are not as complete as moodle, but for e-learning learning, it is very adequate. The features that Schoology has are as follows: Courses, Group, Discussion, Resources, Quiz, Attendance, and Analytics.

The menus contained in the Schoology application include: a) Courses, with courses menu, the users can create new classes, join classes that have already existed or browse through the predefined class list. b) Groups which functions like the wall messages of the group members and can also post on the wall messages. When joining a group, the users can search for parts of the group that the users want. c) Resources are to maintain, to track the documents, files and images that users upload in the class. d) Recent Activity is to display the latest news contained in the account. e) Calendar, to display the calendar page that was posted earlier in the Recent Activity. f) Messages are to send messages or view the messages among the fellow users, and g) People is to be able to see a list of the users in a class.

Yuhdi (2018) explains the steps that can be taken in designing android-based learning using Schoology applications, they are: 1) making courses, 2) using access codes, and 3) adding and managing learning materials with course material. Thus, the design of Androidbased learning media with LMS uses Schoology in Indonesian phonology courses conducted at this stage of the research described in the following sections.

\subsection{Making a course}

In Schoology, we can equate the course as a course/subject, therefore the first step to do the teaching and learning process in Schoology is to create a course. Section names are usually 
used to create classes. In this section, Indonesian Language Phonology courses are taken for the Indonesian Literature Study Program of FBS Unimed class A. By using the section, the lecturer will be facilitated to copy all the material, assignments and exams that have been made in the class.

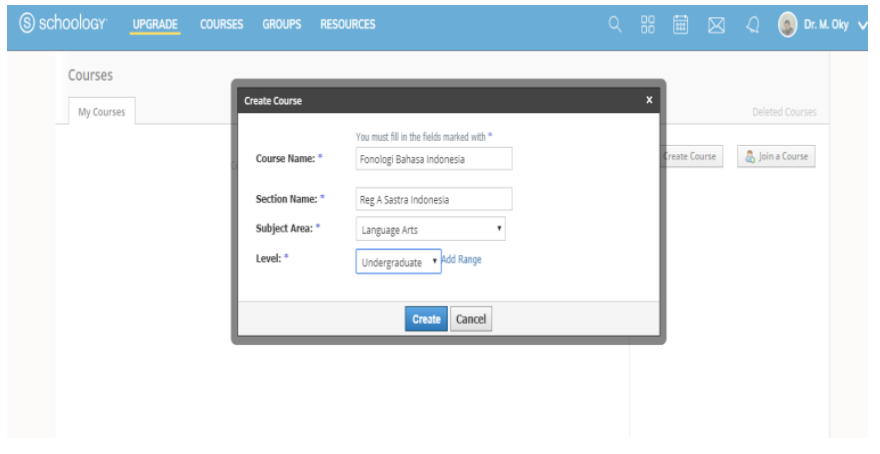

Figure 1. Creating a Course in the Schoology Application

Based on the Figure 1 above, the course created is Indonesian Phonology. At this stage, the lecturer only enters some important information about the identity of the course, such as the name of the subject, the subject/student who follows the learning in the course and the education level.

\subsection{Using the access code}

As a student, to get access to courses that have been prepared by lecturers, the student must have an access code. The use of access code by default is openly which means that anyone who has an access code can directly enter the course that has been created. However, to avoid the double user or unwanted users, it can add features require approval.

Based on the Figure 2 above, the giving of the student code to the students who will take part in online learning in Schoology applications needs to be limited so that the lecturers can ensure that members who are registered in the online class are the students in face-to-face classes. Furthermore, the students and the lecturers will be asked to log in using the RCQKT-X3877 access code previously given by the lecturer. Thus, the students wait for the confirmation from the lecturer to enter into online learning in the Schoology application.

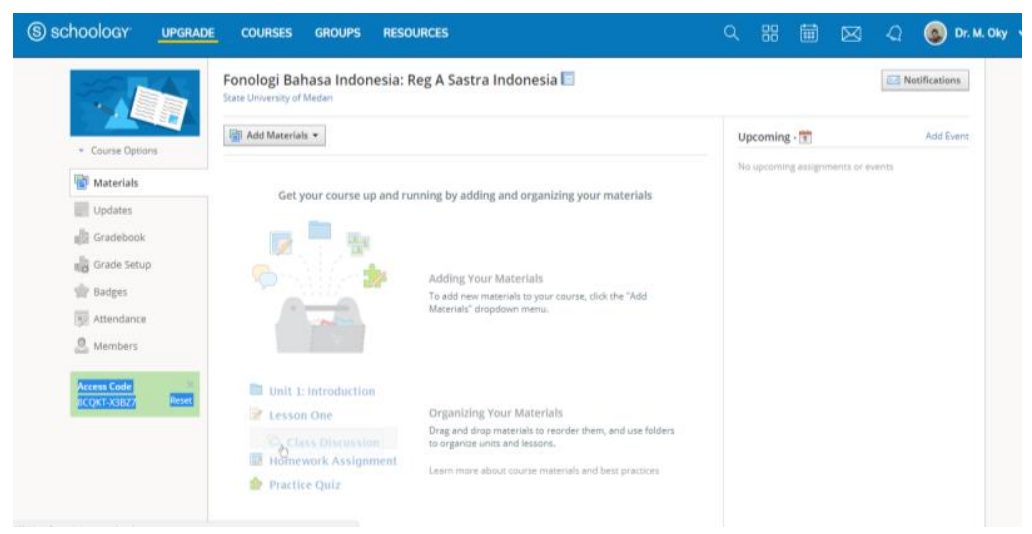


Figure 2. Using Access Code in the Schoology Application

\subsection{Managing the learning materials with course material}

Course material is the main part in a teaching and learning process. This course material is a place to create various needs and teaching and learning process. There are some parts on this course material, they are: 1) Assignments 2) Tests/Quizzes, 3) Files and Links, 4) External Tools, 5) Discussions, 6) Pages, and 7) Media Album. These seven features can be used to support any activities and give assessment. The lecturer can create any tasks for the students on Schoology, by using the button of Add Material which is above the Course Material, then click Add Assignment. Before making the assignment, the lecturer can also make folder at first to arrange the display of the Course Material.

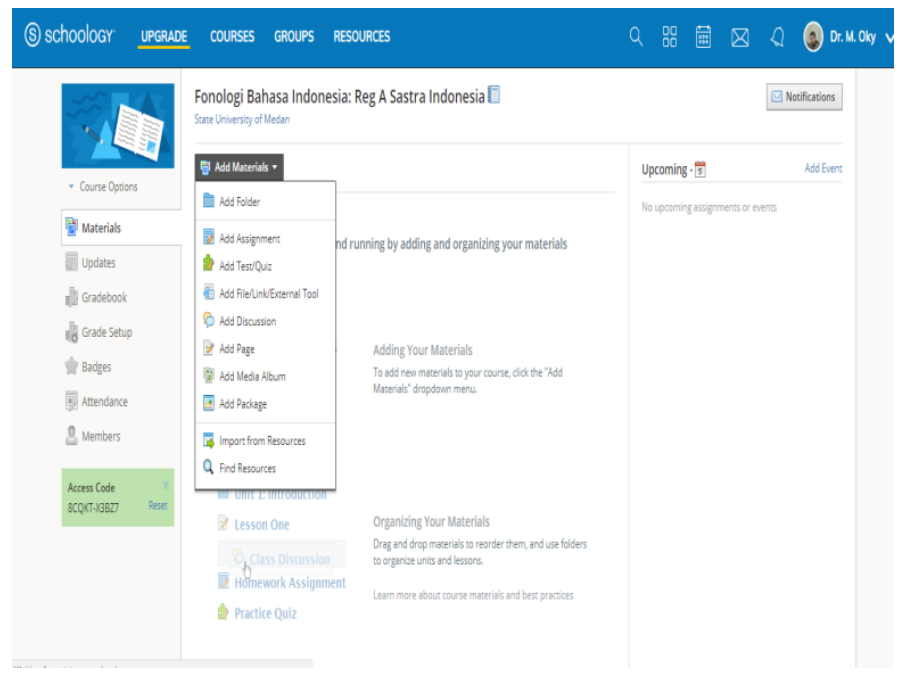

Figure 3.3. above is the management of online learning activities in the Schoology application which in this section consists of several parts, they are: 1) Add Material, 2) Add Assignment, 3) Add Test / Quiz, 4) Add File / Link / External Tool, 5) Add Page, 6) Add Media Album, 5) Add Package, 6) Import from Resources, and 7) Find Resources.

The function of LMS with Schoology application on this course material is as feature for uploading and sharing materials which means that this LMS provides services to upload the documents, making it easier for lecturers to publish teaching material in accordance with the RPS that has been made. This LMS function can also be a forum and chats which means that LMS as an online and chat forum provides two-way communication services between instructors and participants, both synchronously (as a chat) and asynchronous (forum, email). The function of the LMS feature as Quizzes and Survey means that LMS also provides tests in the form of quizzes and survey material so that it can provide Grade in accordance with the test results for students. The function of LMS as Gathering and Reviewing Assignments means that LMS provides an assessment to students in the form of scores related to the results 
of the tests that have been conducted. The function of LMS as Recording Grades means that the LMS will automatically record Grade according to the learning outcomes that have been done by the students.

LMS which uses the Schoology application is also easily accessible from mobile devices. This application can be easily found on the market applications for Apple iOS and Android phones. Mobile tablet devices, such as iPad and Android can also run this application. Students can check the lecturer's views on the tasks they are working on, navigate the course content, review their grades, view the calendar of upcoming assignments, and Communicate with lecturers at any time.

\section{Conclusion}

Based on several explanations as stated above, it can be concluded that the stages of design of android-based learning media products which uses the LMS system with Schoology applications in the Indonesian Phonology course consists of: 1) making courses, 2) using access code, and 3) adding and managing learning material with course material. Thus, the next stage of the framework of this development research activity is to test product validity and test the feasibility of the learning media products produced, as well as the stages of production/dissemination of the learning media products to the public.

\section{References}

[1] Aminoto, T dan Pathoni.: Penerapan Media E-Learning Berbasis Schoology untuk Meningkatkan Aktivitas dan Hasil Belajar Siswa Kelas X SMA di Jambi. Jurnal Sainmatika. Vol. 8, pp. 13-29. https://online-journal.unja.ac.id/index.php/sainmatika/article/view/2222/1561,(2014)

[2] Hamalik, Oemar.: Metode Belajar dan Kesulitan-Kesulitan Belajar. Bandung: Tarsito Huurun'ien, Kansha Isfaraini and Agus Efendi, A. G. Tamrin. (2017). Efektivitas Penggunaan ELearning Berbasis Schoology Dengan Menggunakan Model Discovery Learning Terhadap Prestasi Belajar Siswa SMK Negeri 6 Surakarta Pada Tahun Pelajaran 2015/2016. Vol. 10. Jurnal JIPTEK, Bandung (2017)

[3] Lobo, Fridarlin Magda Noni Wuri.: Pemanfaatan Schoology Untuk Meningkatkan Aktivitas Belajar Siswa (Studi Kasus: Sma Negeri 1 Tengaran),(2016)

[4] Putri Sugiarto dan Devy Meliana.: Pengembangan E-Learning Berbasis Schoology Untuk Meningkatkan Hasil Belajar Siswa Pada Mata Pelajaran Jaringan Dasar Kelas X Tkj. Vol. 2, pp. 136140. Jurnal IT-EDU , (2017)

[5] Yamin, Martinis.: Strategi Pembelajaran Berbasis Kompetensi. Jakarta: Gaung Persada Press.

Yuhdi, A dan Amalia, N. (2018). Desain Media Pembelajaran Berbasis Daring Memanfaatkan Portal Schoology pada Pembelajaran Apresiasi Sastra. Vol. 7, pp. 14-22. JURNAL Basastra Pendidikan Bahasa dan Sastra Unimed, (2006) 